\title{
Chondrogenic Differentiation of Bovine Bone Marrow Mesenchymal Stem Cells (MSCs) in Different Hydrogels: Influence of Collagen Type II Extracellular Matrix on MSC Chondrogenesis
}

\author{
Darko Bosnakovski, ${ }^{1}$ Morimichi Mizuno, ${ }^{2}$ Gonhyung Kim, ${ }^{3}$ Satoshi Takagi, ${ }^{1}$ \\ Masahiro Okumura, ${ }^{1}$ Toru Fujinaga ${ }^{1}$ \\ ${ }^{1}$ Department of Clinical Science, Laboratory of Veterinary Surgery, Graduate School of \\ Veterinary Medicine, Hokkaido University, Sapporo, Japan; telephone: + 1214645 \\ 5915; fax: + 1214648 1960; e-mail: Darko.Bosnakovski@UTSouthwestern.edu; \\ dbosnakovski@yahoo.com \\ ${ }^{2}$ Department of Oral Health Science, Graduate School of Dentistry, Hokkaido \\ University, Sapporo, Japan \\ ${ }^{3}$ Department of Veterinary Surgery, College of Veterinary Medicine, Chungbuk \\ National University, Cheongju, Korea
}

Received 14 September 2005; accepted 6 December 2005

Published online 9 February 2006 in Wiley InterScience (www.interscience.wiley.com). DOI: 10.1002/bit.20828

\begin{abstract}
Bone marrow mesenchymal stem cells (MSCs) are candidate cells for cartilage tissue engineering. This is due to their ability to undergo chondrogenic differentiation after extensive expansion in vitro and stimulation with various biomaterials in three-dimensional (3-D) systems. Collagen type II is one of the major components of the hyaline cartilage and plays a key role in maintaining chondrocyte function. This study aimed at analyzing the MSC chondrogenic response during culture in different types of extracellular matrix (ECM) with a focus on the influence of collagen type II on MSC chondrogenesis. Bovine MSCs were cultured in monolayer as well as in alginate and collagen type I and II hydrogels, in both serum free medium and medium supplemented with transforming growth factor (TGF) $\beta 1$. Chondrogenic differentiation was detected after 3 days of culture in 3-D hydrogels, by examining the presence of glycosaminoglycan and newly synthesized collagen type II in the ECM. Differentiation was most prominent in cells cultured in collagen type II hydrogel, and it increased in a timedependent manner. The expression levels of the of chondrocyte specific genes: sox9, collagen type II, aggrecan, and COMP were measured by quantitative "Real Time" RT-PCR, and genes distribution in the hydrogel beads were localized by in situ hybridization. All genes were upregulated by the presence of collagen, particularly type II, in the ECM. Additionally, the chondrogenic influence of TGF $\beta 1$ on MSCs cultured in collagenincorporated ECM was analyzed. TGF $\beta 1$ and dexamethasone treatment in the presence of collagen type II provided more favorable conditions for expression of the chondrogenic phenotype. In this study, we demon-
\end{abstract}

\section{Correspondence to: Dr. Darko Bosnakovski}

Dr. Bosnakovski's current address is University of Texas, Center for Developmental Biology, Southwestern Medical Center at Dallas, 5323 Harry Hines Blvd., Dallas, TX 75390-9133. strated that collagen type II alone has the potential to induce and maintain MSC chondrogenesis, and prior interaction with TGF $\beta 1$ to enhance the differentiation. (c) 2006 Wiley Periodicals, Inc.

Keywords: mesenchymal stem cells (MSC); chondrogenic differentiation; extracellular matrix; collagen type II

\section{INTRODUCTION}

Stem cells are undifferentiated cells that are defined by their ability, at the single cell level, to self-renew and to differentiate to produce mature progeny cells, which include both nonrenewing progenitors and terminally differentiated effectors (Wagers and Weissman, 2004). Bone marrow mesenchymal stem cells (MSCs) are currently among the best characterized adult stem cells (Majumdar et al., 1998; Pittenger et al., 1999) isolated from various tissue sources such as fat, muscle, and bone (Jiang et al., 2002b; Sottile et al., 2002; Zuk et al., 2002). These cells are able to differentiate into bone, fat, cartilage, muscle tissue, and neurons (Mackay et al., 1998; Reyes et al., 2001; Sekiya et al., 2004; Woodbury et al., 2000) and were ultimately reported in almost all cell lineages (Jiang et al., 2002; Krause et al., 2001). For these reasons, the isolation and manipulation of adult stem cells represents a promising tool for understanding tissue development and regeneration, as well as for studying the engineered repair of tissues and organs (Orlic et al., 2001; Pittenger and Martin, 2004; Wakitani et al., 2002).

The extracellular molecular signaling pathways are being actively investigated. Extracellular signaling involves the interaction of cell surface receptors with soluble cytokines and growth factors, with the extracellular matrix (ECM), 
such as collagen and proteoglycans, or with the surface proteins of the neighboring cells (Heng et al., 2004).

In addition to maintaining the structural integrity of the tissues, the ECM has physiological functions, such as passing nutrients to the cells, acting as a reservoir for physiological mediators, and mediating cellular functions through interaction with cell surface receptors (Comper, 1996). The integrins are a major family of ECM receptors that transmit information from the matrix to the cells, thereby playing a key role in the regulation of cell survival, proliferation, differentiation, and matrix remodeling (Loeser, 2002).

Articular cartilage is an avascular tissue composed of chondrocytes and ECM, which predominantly consists of collagen type II, aggrecan, and hyaluronic acid. In addition to these macromolecules, collagen types VI, IX, XI; decorin; biglycan, cartilage oligomeric matrix protein (COMP); and fibromodulin are also present in minor concentrations (Muir, 1995; Poole et al., 2001). It is well known that damaged articular cartilage has poor intrinsic regenerative capacity. Cell therapy using chondrocytes or their precursors embedded in some biocompatible scaffold is a possible approach for hyaline cartilage reconstruction. Such threedimensional (3-D) support is required for articular chondrocytes to maintain their differentiated phenotype in vitro or for the MSC to undergo chondrogenesis (Lemare et al., 1998). Materials such as agarose, collagen, fibrin, alginate, and biopolymers have all been used as 3-D scaffolds for chondrocytes and MSC cultures (Batorsky et al., 2005; Huang et al., 2004; Kavalkovich et al., 2002; Mueller and Glowacki, 2001; Ponticiello et al., 2000; Wayne et al., 2005).

In order to induce MSC chondrogenesis, factors that support strong cell-cell interaction, growth factors, and an environment that maintains spherical morphology, such as polymer gels, are all important. Strong cell-cell interaction mediated by cell adhesion molecules such as $N$-cadherin and integrins allow MSC conversion to prechondroblasts at the precartilage mesenchymal condensation stage during limb development (Haas and Tuan, 1999; Hall and Miyake, 1995). Various bioactive factors, such as fibroblast growth factor, transforming growth factors (TGF) $\beta 1$ and $\beta 3$, bone morphogenic proteins (BMPs)-2, -6 , and -9 , and insulin-like growth factors, have been reported to induce or maintain chondrogenesis (Indrawattana et al., 2004; Muraglia et al., 2000; Sekiya et al., 2002).

Although there has been an increase in information regarding the role of growth factors and cytokines as inducers and mediators of MSC differentiation, little is known about the influence of ECM on MSC chondrogenic differentiation. Even less is known regarding the nature of communication and the mechanism of interaction between the MSCs and the cartilaginous matrix during embryogenesis or homeostasis of articular cartilage.

The goals of this study were to analyze the influence of different types of ECM, particularly collagen type II, on MSC chondrogenesis with or without interaction with the chondrogenic growth factor TGF $\beta 1$. Ultimately, these studies may contribute to a better understanding of the development, physiology, and regeneration of articular cartilage.

\section{MATERIALS AND METHODS}

\section{Harvest and Isolation of Bovine MSC}

Bone marrow was aspirated from four calves ( 2 months old), and MSCs were isolated by previously described methods (Bosnakovski et al., 2004, 2005). Briefly, the bone marrow sample was washed twice with phosphate buffered saline (PBS), and twice again with Dulbecco's Modified Eagle Medium (DMEM; GIBCO BRL, Grand Islands, NY). After determination of the cell viability and number, $5 \times 10^{4} / \mathrm{cm}^{2}$ nucleated cells were plated in medium that consisted of DMEM (low glucose) containing penicillin G $100 \mathrm{U} / \mathrm{mL}$, streptomycin $100 \mu \mathrm{g} / \mathrm{mL}$, amphotericin B $0.25 \mu \mathrm{g} / \mathrm{mL}$, HEPES $2.4 \mathrm{mg} / \mathrm{mL}, \mathrm{NaHCO}_{3} 3.7 \mathrm{mg} / \mathrm{mL}$, and $10 \%$ fetal bovine serum (FBS; lot No. 5300C, ICN, Biomedicals, Aurora, $\mathrm{OH}$ ), and cultured at $37^{\circ} \mathrm{C}$ in a humidified atmosphere containing $5 \% \quad \mathrm{CO}_{2}$ until the second passage. Experiments were performed with at least six different isolated cell lines.

\section{Hydrogel Preparation}

Alginate and collagen type I and II hydrogels were prepared using a combination of previously reported protocols (Elisseeff et al., 2002; Qi and Scully, 2002). An alginate solution $(1.5 \%)$ prepared from low-viscosity sodium alginate (Wako Pure Chemical Co., Osaka, Japan) in $0.15 \mathrm{M} \mathrm{NaCl}$ was sterilized by filtering through a $0.45 \mu \mathrm{m}$ filter. For preparation of collagen type I or II hydrogels, $700 \mu \mathrm{L}$ of collagen type I or II solutions $(0.3 \%$, Koken Co., Tokyo, Japan) were neutralized with $100 \mu \mathrm{L}$ HEPES buffer and mixed with $280 \mu \mathrm{L} 1.5 \%$ alginate solution. A minimum of $35 \%$ alginate in the mixture was necessary to obtain a solid hydrogel. Cells from the second or third passage were harvested with $0.25 \%$ trypsin in $0.02 \%$ EDTA, and then divided in three parts. Each part was mixed with one of the hydrogels to a final concentration of $1-2 \times 10^{6}$ cells/mL solution. Cells/hydrogel suspension was slowly dropped into $102 \mathrm{mM} \mathrm{CaCl}_{2}$ using a pipette tip $(2-200 \mu \mathrm{L})$. After initial gelatinization, the beads were allowed to polymerize for $10 \mathrm{~min}$. Subsequently, they were washed three times with $0.15 \mathrm{M} \mathrm{NaCl}$ and once with DMEM and were cultured overnight at $37^{\circ} \mathrm{C} / 5 \% \mathrm{CO}_{2}$. The polymerized alginate solution formed compact spherical beads of 2-3 mm diameter. Collagen type I and II hydrogels had a more discoid shape, approximately $2 \times 4 \mathrm{~mm}$ in size. They could not polymerize to typical beads prior to contact with $\mathrm{CaCl}_{2}$ because of the low alginate concentrations. On the following day, the beads were transferred to six-well cell culture plates ( 16 beads/well), and they were cultured in plain or chondrogenic medium for 21 days. The plain medium was a serum-free chemically defined medium consisting of DMEM (high glucose), insulin $6.25 \mu \mathrm{g} / \mathrm{mL}$, transferin $6.25 \mu \mathrm{g} / \mathrm{mL}$, selenious acid $6.25 \mu \mathrm{g} / \mathrm{mL}$, bovine serum 
albumin $1.25 \mathrm{mg} / \mathrm{mL}$, pyruvate $1 \mathrm{mM}$, linoleic acid $5.35 \mu \mathrm{g} /$ $\mathrm{mL}$, and ascorbate 2-phosphate $50 \mu \mathrm{g} / \mathrm{mL}$ (all from Sigma Chemical Co., St. Louis, MO). The chondrogenic medium was plain medium supplemented with $10 \mathrm{ng} / \mathrm{mL}$ TGF $\beta 1$ (R \& D Systems, Minneapolis, MN) and $100 \mathrm{nM}$ dexamethasone (Sigma Chemical Co.).

MSCs cultured in monolayers were used as a control, for comparing the influence of the type of culture system (monolayer and 3-D) on chondrogenesis. Aliquots of the cells used for hydrogel preparation were plated $(5 \times$ $10^{3}$ cells $/ \mathrm{cm}^{2}$ ) in six-well plates and cultured in plain and chondrogenic medium under conditions similar to those of cells in hydrogels.

\section{Histological and Immunohistochemical Analysis of the Hydrogel Beads}

Samples were harvested at the beginning of the experiment (day 0 ) and after 3, 6, and 21 days of culture. They were fixed in $10 \%$ neutral buffered formalin containing $0.1 \mathrm{M} \mathrm{CaCl}_{2}$ for 2 days and embedded in paraffin. Hematoxylin and eosin $(\mathrm{H} \& \mathrm{E})$ staining of paraffin sections $(4 \mu \mathrm{m})$ was performed to evaluate cell morphology in the beads. Sulfated glycosaminoglycans (GAGs) were visualized by staining with $0.5 \%$ alcian blue (pH 1.0) for 10 min. Newly synthesized collagen type II was detected using polyclonal rabbit anti-bovine antibody (LSL Co., Tokyo, Japan). Briefly, after deparaffinization, the sections were predigested with $2.5 \%$ hyaluronidase (Type I-S, Sigma Chemicals Co.) for $30 \mathrm{~min}$ at $37^{\circ} \mathrm{C}$ to facilitate antibody access. Endogenous peroxidase was quenched by treatment with $0.3 \% \mathrm{H}_{2} \mathrm{O}_{2}$ in methanol at room temperature for $30 \mathrm{~min}$, and nonspecific antibody binding was blocked by incubating sections in $10 \%$ normal goat serum at $37^{\circ} \mathrm{C}$ for $30 \mathrm{~min}$. Primary antibody was diluted 1:500 in $0.05 \mathrm{M}$ Tris buffer ( $\mathrm{pH}$ 7.6) and applied overnight at $4^{\circ} \mathrm{C}$. Sections were then incubated with the secondary antibody, swine anti-rabbit immunoglobulin (DAKO, Glostrup, Denmark), for 60 min, followed by detection with the rabbit PAP kit (DAKO). Collagen type II was visualized by reactions with $0.05 \%$ diaminobenzidine containing $0.01 \%$ $\mathrm{H}_{2} \mathrm{O}_{2}$.

\section{In Situ Hybridization}

For in situ hybridization, hydrogel beads harvested on day 0 , 3,6 , and 21 were embedded in OCT embedding medium (Tissue-Tek; Sakura Finetechnical Co., Tokyo, Japan) and frozen in liquid nitrogen. Frozen sections $(10 \mu \mathrm{m})$ were cut and mounted on silane-coated glass slides. Two kinds of nonoverlapping 45-m antisense oligonucleotide probes were synthesized to detect every mRNA of interest. The following genes sequences were used: for collagen type I, nucleotide residues 2408-2453 and 4108-4153 (Gen Bank AB008683); for collagen type II, nucleotide residues 278323 and 777-822 (Gen Bank X02420); and for aggrecan, nucleotide residues 5540-5585 and 6750-6795 (Gen Bank U76615). Oligonucleotides were labeled with ${ }^{35} S$-adenosine thiotriphosphate to a specific activity of $0.5 \times 10^{9} \mathrm{dpm} / \mu \mathrm{g}$
DNA, using terminal deoxynucleotidyl transferase. Sections were fixed with $4 \%$ paraformaldehyde in $0.05 \mathrm{M}$ Tris buffer (pH 7.6) for $15 \mathrm{~min}$, and acetylated with $0.25 \%$ acetic anhydride in $0.1 \mathrm{M}$ triethanolamine- $\mathrm{HCl}(\mathrm{pH} 8.0$ ) for $10 \mathrm{~min}$. Hybridization was performed at $42^{\circ} \mathrm{C}$ overnight by reaction with labeled oligonucleotide probes at a final radioactivity of $0.5 \times 10^{7} \mathrm{cpm} / \mathrm{mL}$ in $50 \%$ formamide, which contained $30 \mathrm{mM}$ Tris- $\mathrm{HCl}$ (pH 7.4), 0.6 M NaCl, $1 \mathrm{mM}$ EDTA, $100 \mathrm{mM}$ dithiothreitol, $1 \times$ Denhardt's solution, $0.25 \%$ sodium dodecyl sulfate, $10 \%$ dextran sulfate, and $200 \mu \mathrm{g} /$ $\mathrm{mL}$ yeast tRNA. Control hybridization was performed in the presence of 20-fold excess amount of unlabeled antisense probe. Slides were washed in $2 \times$ SSC containing $0.1 \%$ sarkosyl for $30 \mathrm{~min}$ at room temperature, followed by washing twice in $0.1 \times \mathrm{SSC} / 0.1 \%$ sarkosyl for $40 \mathrm{~min}$ at $55^{\circ} \mathrm{C}$. Slides were dipped into autoradiographic emulsion (NTB-2, Kodak, Rochester, NY), exposed at $4^{\circ} \mathrm{C}$ for 3 weeks, and counterstained with hematoxylin.

\section{Isolation of RNA From the Hydrogels and cDNA Synthesis}

On days $0,3,6$, and 21 , beads $(n=6-8)$ were transferred to $1.5 \mathrm{~mL}$ centrifuge tubes and dissolved with $1 \mathrm{~mL}$ reconstruction buffer (50 mM EDTA and $10 \mathrm{mM}$ HEPES in $0.15 \mathrm{M} \mathrm{NaCl}$ ) for $10 \mathrm{~min}$ at $37^{\circ} \mathrm{C}$. The cell suspension was centrifuged (200g) and the cell pellets were washed once with PBS. Total RNA from reconstructed cells and cells from the monolayer was isolated using Trizol (Invitrogen, Life Technologies, Carlsbad, CA) according to the manufacturer's instructions. Samples were treated with DNase to remove possible genomic DNA contamination. Subsequently, first-strand cDNA was synthesized in a $20 \mu \mathrm{L}$ reaction mixture from $2 \mu \mathrm{g}$ total RNA using M-MLV reverse transcriptase (Invitrogen) with oligo $(\mathrm{dT})_{20}$ as a primer. The sample that did not contain transcription enzyme in the reaction mixture was used as the negative control for checking genomic contamination.

To compare level of MSC chondrogenesis and for positive control in PCR reaction, total RNA was harvested from bovine chondrocytes that were isolated by collagenase digestion of articular cartilage pieces from the same donors as those for bone marrow (Bosnakovski et al., 2004).

\section{Measurement of Gene Expression by a Quantitative "Real Time" RT-PCR (qRT-PCR) Method}

The amount of cDNA was measured by a qRT-PCR method using the Smart Cycler System (Cepheid, CA). The PCR reaction was carried out in $25 \mu \mathrm{L}$ final volume, which contained PCR buffer, $3 \mathrm{mM} \mathrm{MgCl}_{2}, 0.3 \mathrm{mM}$ dNTP mixture, $0.3 \mu \mathrm{M}$ each of bovine specific primer (Table I), and Taq polymerase (1.25 U/tube; Takara Biomedicals, Otsu, Japan). Thermal cycling was carried out for 45 cycles at $95^{\circ} \mathrm{C}$ for $5 \mathrm{~s}$, $55-60^{\circ} \mathrm{C}$ for $15 \mathrm{~s}$, and $75^{\circ} \mathrm{C}$ for $15 \mathrm{~s}$. The amount of PCR product was estimated using absolute quantification method; 
Table I. Bovine marker genes used in quantitative "Real Time" RT-PCR (qRT-PCR).

\begin{tabular}{|c|c|c|c|}
\hline Gene & Primer nucleotide sequence & Product size (bp) & Accession number \\
\hline GAPDH & $\begin{array}{l}\text { Forward 5' CCT TCATTG ACC TTC ACT ACATGG TCTA } \\
\text { Reverse } 5^{\prime} \text { TGG AAG ATG GTG ATG GCC TTT CCATTG }\end{array}$ & 127 & U85042 \\
\hline Collagen type I & $\begin{array}{l}\text { Forward 5' TGC TGG CCA ACC ATG CCT CT } \\
\text { Reverse } 5^{\prime} \text { CGA CAT CAT TGG ATC CTT GCA G }\end{array}$ & 120 & $\mathrm{AB} 008683$ \\
\hline Collagen type II & $\begin{array}{l}\text { Forward 5' ATC CAT TGC AAA CCC AAA GG } \\
\text { Reverse } 5^{\prime} \text { CCA GTT CAG GTC TCT TAG AG }\end{array}$ & 147 & X02420 \\
\hline Collagen type X & $\begin{array}{l}\text { Forward 5' CAT GCT GCC ACA AAC AGC } \\
\text { Reverse } 5^{\prime} \text { TGG ATG GTG GGC CTT TTA }\end{array}$ & 110 & X53556 \\
\hline Aggrecan & $\begin{array}{l}\text { Forward 5' CAC TGT TAC CGC CAC TTC CC } \\
\text { Reverse } 5^{\prime} \text { GAC ATC GTT CCA CTC GCC CT }\end{array}$ & 303 & U76615 \\
\hline Sox9 & $\begin{array}{l}\text { Forward 5' CAT GAA GAT GAC CGA CGA G } \\
\text { Reverse } 5^{\prime} \text { CGT CTT CTC CGT GTC GGA }\end{array}$ & 118 & AF278703 \\
\hline COMP & $\begin{array}{l}\text { Forward } 5^{\prime} \text { TTC GGA ACG CAC TGT GG } \\
\text { Reverse } 5^{\prime} \text { TGC AGG AAC CAG CGG TA }\end{array}$ & 112 & X74326 \\
\hline
\end{tabular}

by measuring the intensity of the fluorescence of SYBR Green I interacted into the PCR product and compared to the standard curve of every gene, separately. The mRNA expression levels of target genes were normalized by dividing their value by the value of the glyceraldehyde-3-phosphate dehydrogenase (GAPDH) mRNA level. The quality of the PCR products was checked by melting curve analysis, electrophoresis, and sequencing.

\section{Statistical Analyses}

Data were evaluated from at least six independent experiments and are represented as mean $\pm \mathrm{SD}$. One-Way ANOVA followed by multiple pairwise comparisons was performed to determine differences among the groups. The results were considered significantly different at $P<0.05$.

\section{RESULTS}

\section{Histological and Immunohistochemical Determination of the Chondrogenesis}

To evaluate the effect of various ECM components on chondrogenesis, we cultured bovine MSCs in hydrogels composed of alginate, collagen type I and II. Structural organization and cell proliferation, deposition of sulfated GAG, and the presence of newly synthesized collagen type II in hydrogels were analyzed on days $0,3,6$, and 21 , by $\mathrm{H} \& \mathrm{E}$, alcian blue, and immunohistochemical staining, respectively, (Fig. 1). Homogeneous cell distribution throughout the bead was observed in all types of hydrogels. During the culture period, the cells proliferated in all types of cultures, with a notable increased proliferation rate in collagen hydrogels and in chondrogenic medium (data not shown). Cells maintained a round plump shape, characteristic of chondrocytes, and formed cell clusters during the culture period. Chondrogenesis was detected in all hydrogels, regardless of the type of culture medium (plain or chondrogenic). Detected GAG and collagen type II gradually increased during the culture period, and the difference in the staining intensity at day 0 and day 21 was obvious under all experimental conditions (Fig. 1). Among the various types of hydrogel and media, the chondrogenic markers were best expressed in cells cultured in collagen type II ECM and in chondrogenic medium, respectively. However, prior interpretation of the results it has to be considered that all three types of hydrogels have different physical properties (density, porosity, water contents, cells seeding efficiency), which can influence proliferation and differentiation ability of the cells.

In the present trial, MSCs from the second or third passage, independently, were used for the preparation of hydrogels. Cells from these two passages did not show any significant difference in the potential to undergo chondrogenic differentiation.

\section{Quantitative Analyses of Chondrocyte-Related Gene Expression}

Gene expression was analyzed by qRT-PCR in the differentiated cells produced by the various culture conditions (monolayer and 3-D culture), ECM (alginate and collagen types I and II), and culturing medium (plain serum-free and chondrogenic-TGF $\beta 1 /$ dexamethasone supplemented medium). We assayed panel of chondrocyte-related genes: collagen type II (coll 2), aggrecan (agg), COMP, early chondrogenic transcription factor sox 9 , and a marker for hypertrophic chondrocytes, collagen type X (coll 10).

Cells cultured in monolayers in serum-free medium expressed only basal levels of agg, coll 2, and coll 10 mRNA, but not of sox 9 and COMP. Conversely, cells cultured in 3-D systems, in plain medium, began to express or significantly increased the expression of chondrogenic genes just after 3 days (Figs. 2A and 3A). Sox 9 showed markedly different expression between cells cultured in monolayers and in 3-D culture, being detection in all hydrogels, regardless of the medium (Fig. 4A). Sox9 is a member of the Sox (Sry-type HMG box) gene family, which are predominantly expressed in mesenchymal condensation and cartilage, and has been shown to activate type II collagen and aggrecan (Tsuchiya et al., 2003). We observed coll 2, 


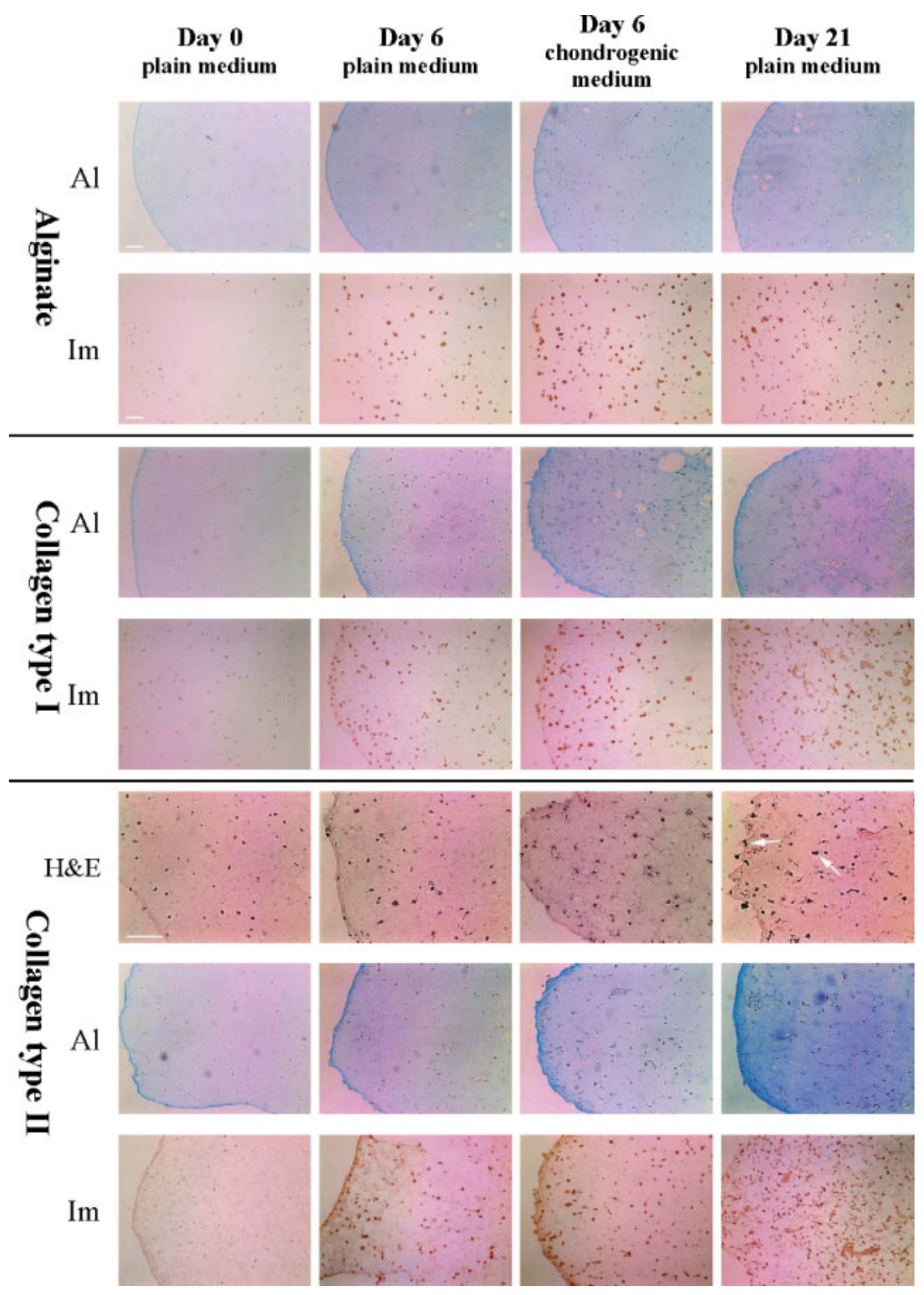

Figure 1. Mesenchymal stem cells (MSCs) cultured in alginate, and collagen types I and II hydrogels on days 0, 6, and 21 in serum-free and chondrogenic media, analyzed by hematoxylin and eosin ( $\mathrm{H} \& \mathrm{E})$, alcian blue (Al), and immunohistochemical staining $(\mathrm{Im})$ for detection of type II collagen. Cells had a round, plump shape throughout the beads. Cell proliferation was obvious during the culture period, and on day 21, cells organized in clusters were noticeable (white arrows). Further, a significantly increased proliferation rate was detected in beads cultured in TGF $\beta 1$ supplemented medium. Positive metachromatic staining and immunoreactivity for type II collagen was detected on day 3 , and the intensity increased in a time-dependent manner. Scale bar $125 \mu \mathrm{m}$. [Color figure can be seen in the online version of this article, available at www.interscience.wiley.com.]

agg, and COMP expression at a later time point in 3D culture, consistent with an early activating role of sox 9 . The levels of coll 2 and agg mRNA continued to increase in collagen type I and II hydrogels from day 3 to day 21; however, they were maintained constant in alginate hydrogel.
In collagen type II hydrogel, from day 0 to day 6 and day 0 to day 21, coll 2 increased 99- and 155-fold, and agg increased 12- and 31-fold, respectively (Figs. 2A and 3A). In alginate, on day 3 , coll 2 and agg were upregulated approximately 40 -fold and threefold, respectively, and this 
a
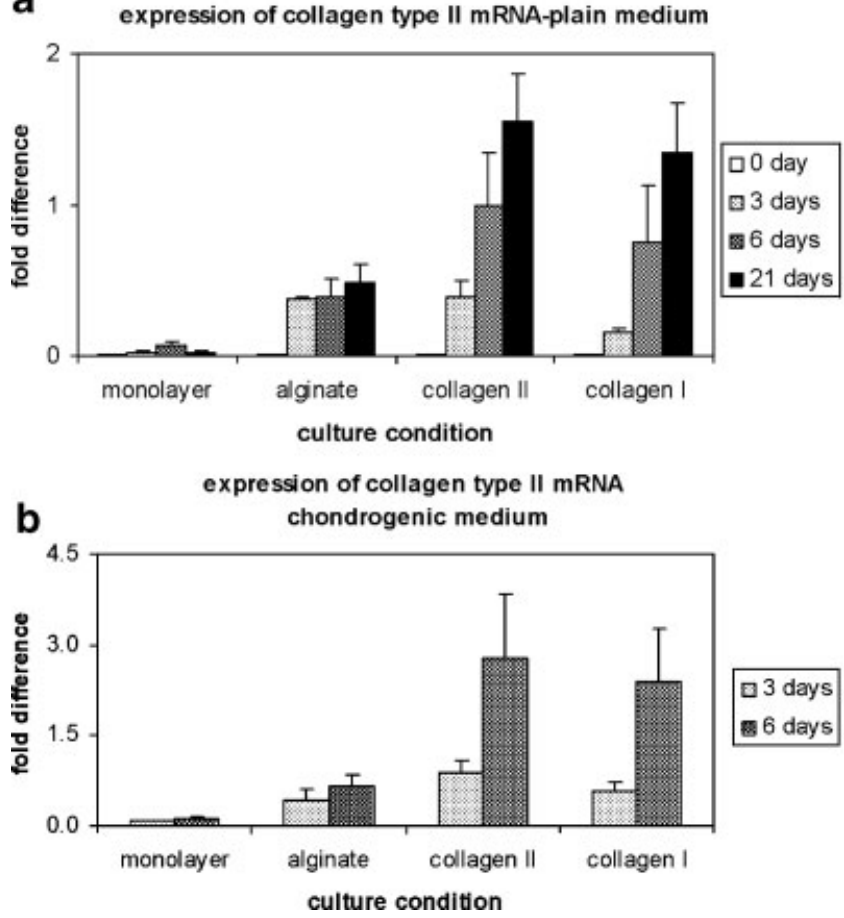

Figure 2. Quantitative analysis of collagen type II ( coll 2) gene expression of MSCs cultured in plain (serum-free: (a)) and chondrogenic (TGF $\beta 1 /$ dexamethasone: (b) media. The expression level was normalized with respect to the expression level of GAPDH mRNA. The expression level of coll 2 mRNA in the collagen type II hydrogel in plain medium on day 6 was represented as one. Data were evaluated from seven independent experiments and were represented as mean $\pm \mathrm{SD}$.

expression level remained constant during the culture period. Collagen types I or II incorporated in ECM significantly induced the expression of coll $2 \mathrm{mRNA}$, and on day 21 , it showed approximately 3.2 -fold increase over that of alginate beads $(P<0.05)$. The expression of agg mRNA was also highest in the cells cultured in collagen type II, and on day 21 it showed 3.2- and 1.9-fold increase over that of alginate and collagen type I hydrogels $(P<0.01)$, respectively. In addition to the chondrogenic effect of the different 3-D cultures, we analyzed the influence of interaction among cells, ECM, and the potent bioactive factors, TGF $\beta 1$ and dexamethasone on MSC differentiation. MSCs in monolayers stimulated by TGF $\beta 1$ demonstrated increased but limited chondrogenic gene expression. The effect of this chondrogenic biofactor on gene expression was greatly enhanced in the 3-D culture system, followed by deposition of newly synthesized collagen type II in the ECM (Fig. 1). In the collagen type II hydrogel, on day 6 , the coll 2 mRNA was upregulated 2.8-fold in the chondrogenic medium in comparison with the plain medium $(P<0.05$; Fig. 2). Interestingly, TGF $\beta 1$ had a suppressive effect on agg mRNA, and on day 6, the expression decreased $30 \%$ in comparison with the plain medium (Fig. 3). A significant difference $(P<0.01)$ between the plain and chondrogenic media was found in all hydrogels, with approximately fivefold higher expression of COMP mRNA (Fig. 4B).

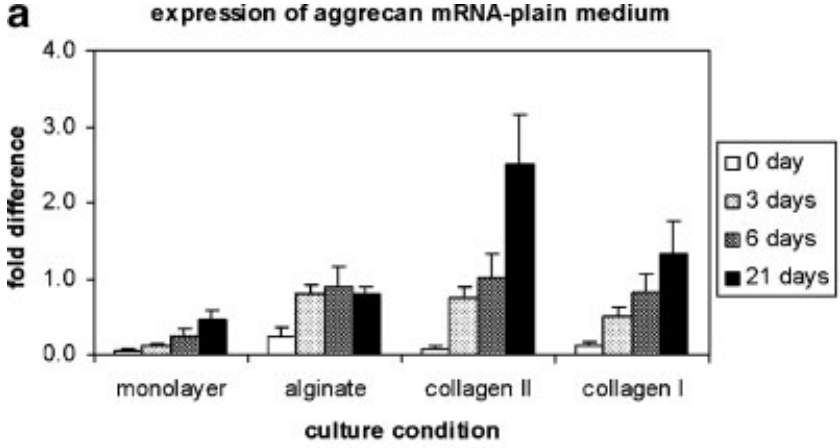

b expression of aggrecan mRNA-chondrogenic medium

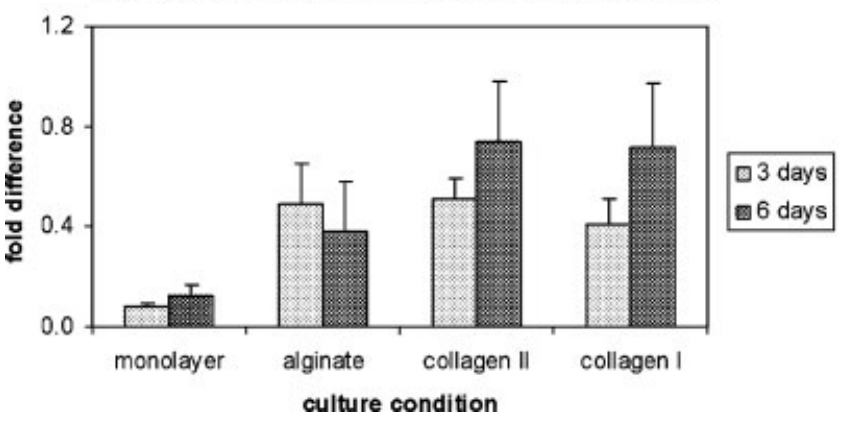

Figure 3. Quantitative analysis of aggrecan (agg) gene expression of MSCs cultured in plain (a) and chondrogenic (b) media. The expression level was normalized with respect to the expression level of GAPDH mRNA. The expression level of agg mRNA in the collagen type II hydrogel in plain medium on day 6 was represented as one. Data were represented as mean $\pm \mathrm{SD}$.

COMP is one of the major noncollagenous proteins in cartilage and is reported to be an even more sensitive marker than collagen type II for the differentiation state of bovine articular chondrocytes (Zaucke et al., 2001). The expression of sox 9 and coll 10 was also stimulated by TGF $\beta 1$ (Fig. 4A and B); for example, in collagen type II ECM, after 6 days of culture, coll 10 increased 1.8 -fold in chondrogenic medium over plain medium $(P<0.05)$. Collagen type $\mathrm{X}$ is a marker for hypertrophic cartilage, which undergoes endochondral ossification and for articular chondrocytes that have become hypertrophic in osteoarthritis (Eerola et al., 1997; Gibson et al., 1997).

Additionally, we analyzed the influence of the ECM and the type of medium on the expression of coll 1 mRNA in MSCs (Fig. 5). This gene is one of the markers for the dedifferentiation of chondrocytes (Schulze-Tanzil et al., 2002). During culturing in monolayer, chondrocytes shift expression from coll 2 to coll 1 . MSCs cultured in monolayers and alginate cultures tended to increase coll 1 expression (Fig. 5A). On the other hand, cells cultured for 21 days in collagen type I and particularly type II hydrogels showed a 2.3- and 2.8-fold decrease in expression compared with that of alginate $(P<0.05$ and $P<0.01)$. In all culture conditions except collagen type I ECM, the coll 1 mRNA was significantly $(P<0.01)$ downregulated by the chondrogenic medium, compared with the same experimental group cultured in plain medium. 

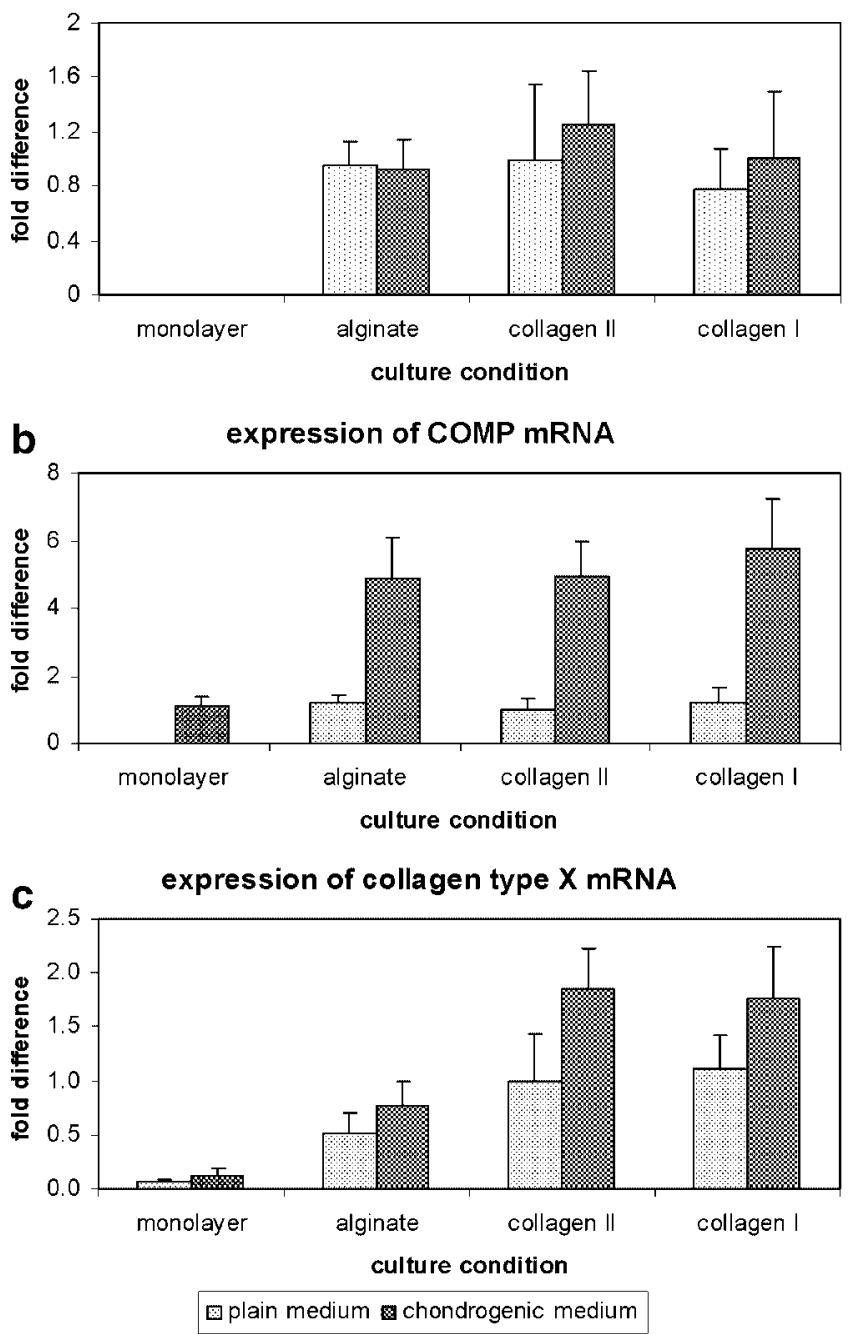

Figure 4. Quantitative analysis of $\operatorname{sox} 9(\mathbf{a}), \operatorname{COMP}(\mathbf{b})$, and collagen type $\mathrm{X}$ (coll 10; (c)) gene expression in MSCs cultured for 6 days. The expression level was normalized based on the GAPDH mRNA level. Expression levels of sox9, COMP, and coll $10 \mathrm{mRNA}$ in the collagen type II hydrogel in plain medium were each represented as one. Values were expressed as mean $\pm \mathrm{SD}$.

We compared gene expression level in chondrocytes produced in vitro (MSCs cultured for 6 days in collagen type II hydrogels and in chondrogenic medium) to that of primary isolated chondrocytes, cultured overnight in monolayers (Table II). While coll 2, agg, and COMP could be detected at responsibly similar levels, primary chondrocytes expressed very low to undetectable level of sox 9 , coll 10 , and coll 1 . Expression of sox 9 in freshly isolated chondrocytes could not be detected under equivalent RT-PCR conditions. However, with increasing sensitivity of the reactions, a low expression level of this gene was also detected (data not shown).

\section{Localization of Gene Expression in the Hydrogels}

In order to confirm the results from qRT-PCR and to localize mRNA expression in the hydrogel beads, we performed in situ hybridization for coll 1, coll 2, and agg mRNA (Figs. 6-8). The highest level of coll 2 and agg expression
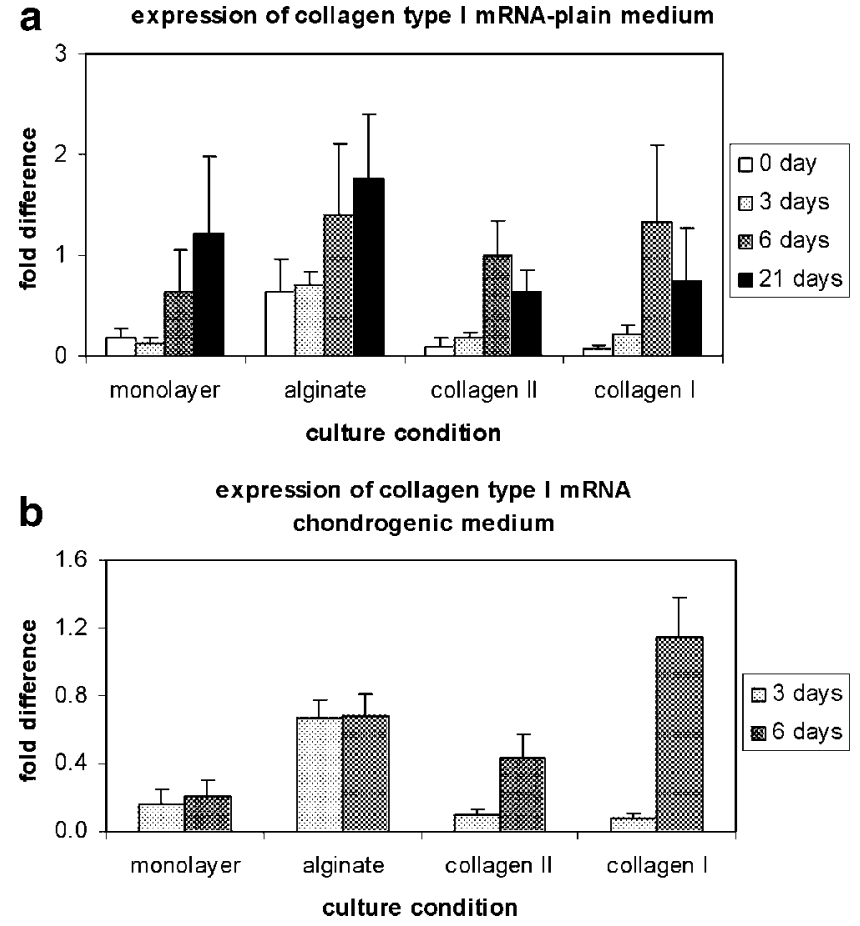

Figure 5. Quantitative analyses of collagen type I ( coll 1) gene expression of MSCs cultured in plain (a) and chondrogenic (b) media. The expression level was normalized with respect to the expression level of GAPDH mRNA. The expression level of coll $1 \mathrm{mRNA}$ in the collagen type II hydrogel in plain medium on day 6 was represented as one. Data were represented as mean \pm SD.

was detected in cells cultured in collagen type II ECM. The intensity of the signal increased with culture time and with the presence of TGF $\beta 1$ in the medium. After 21 days of culture in plain medium, distribution of coll 2 mRNA was evident in the center of the collagen bead. On the other hand, after short (6 days) treatment with TGF $\beta 1$, coll 2 was prominently detected in the cells at the periphery of the beads. This pattern of coll 2 mRNA distributions was not notable in the alginate beads. Similar to coll 2, strong coll 1 mRNA expression was detected in the center of the collagen type I hydrogel after 21 days of culture in plain medium. The incorporated collagen was most concentrated in the center of the beads where expression of chondrogenic-related genes

Table II. qRT-PCR analyses of chondrocyte-related gene expression in mesenchymal stem cells (MSCs) cultured for 6 days in collagen type II hydrogel and chondrogenic medium, and primary chondrocytes cultured overnight in $10 \%$ FBS-supplemented medium.

\begin{tabular}{lll}
\hline Gene & MSC & Chondrocytes \\
\hline Collagen type II & $1.00 \pm 0.38$ & $1.89 \pm 0.21$ \\
Aggrecan & $1.00 \pm 0.33$ & $1.70 \pm 0.36$ \\
Sox9 & $1.00 \pm 0.31$ & Not detected \\
COMP & $1.00 \pm 0.22$ & $0.42 \pm 0.07$ \\
Collagen type X & $1.00 \pm 0.21$ & $0.03 \pm 0.01$ \\
Collagen type I & $1.00 \pm 0.32$ & $0.01 \pm 0.003$ \\
\hline
\end{tabular}

The gene expression level in MSC was represented as $1 \pm \mathrm{SD}$ and that in chondrocytes was represented as fold difference \pm SD. 


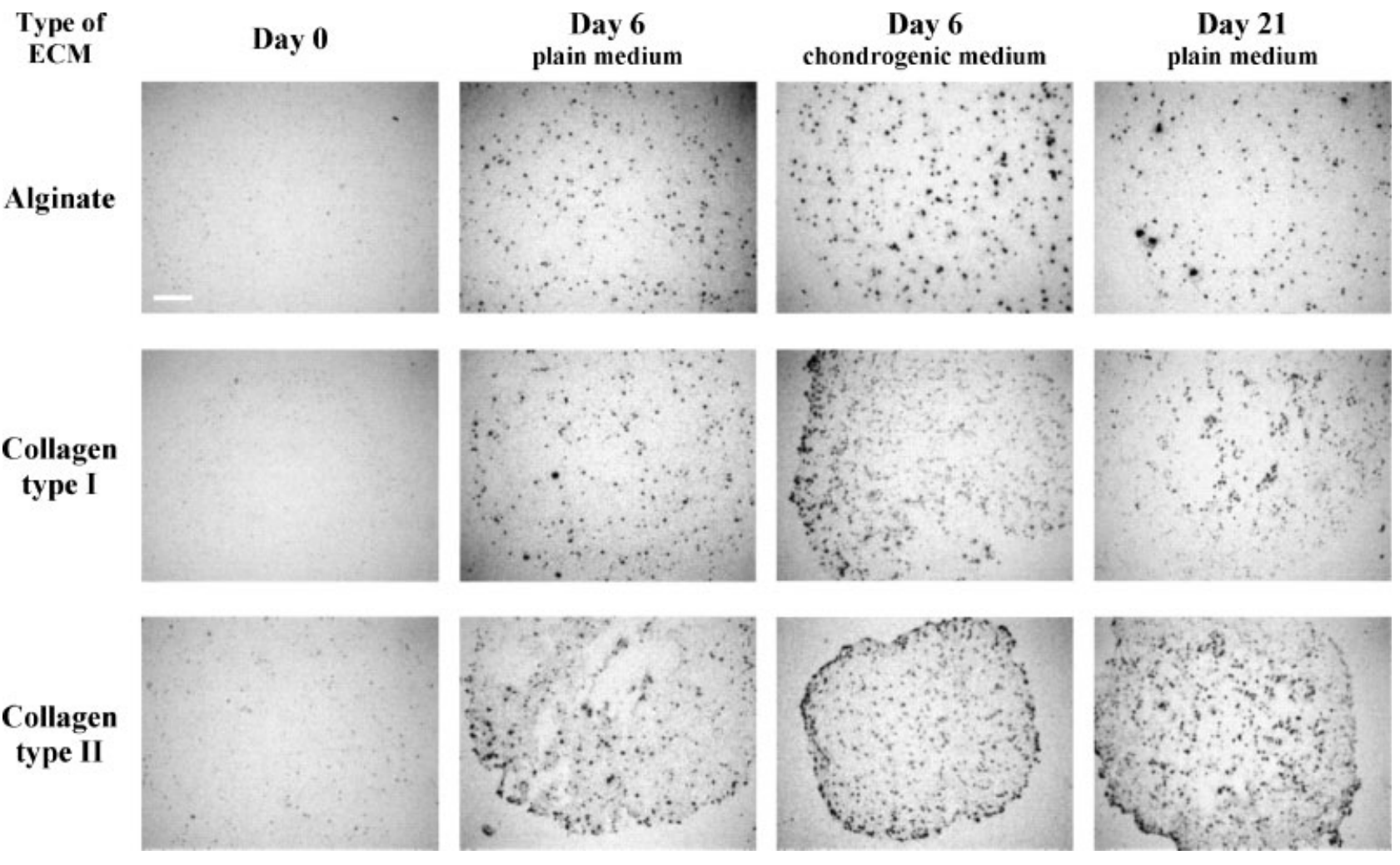

Figure 6. In situ hybridization of the alginate, collagen type I and II hydrogels on day 0, 6, and 21 for detection of coll 2 mRNA. Scale bar $250 \mu \mathrm{m}$.

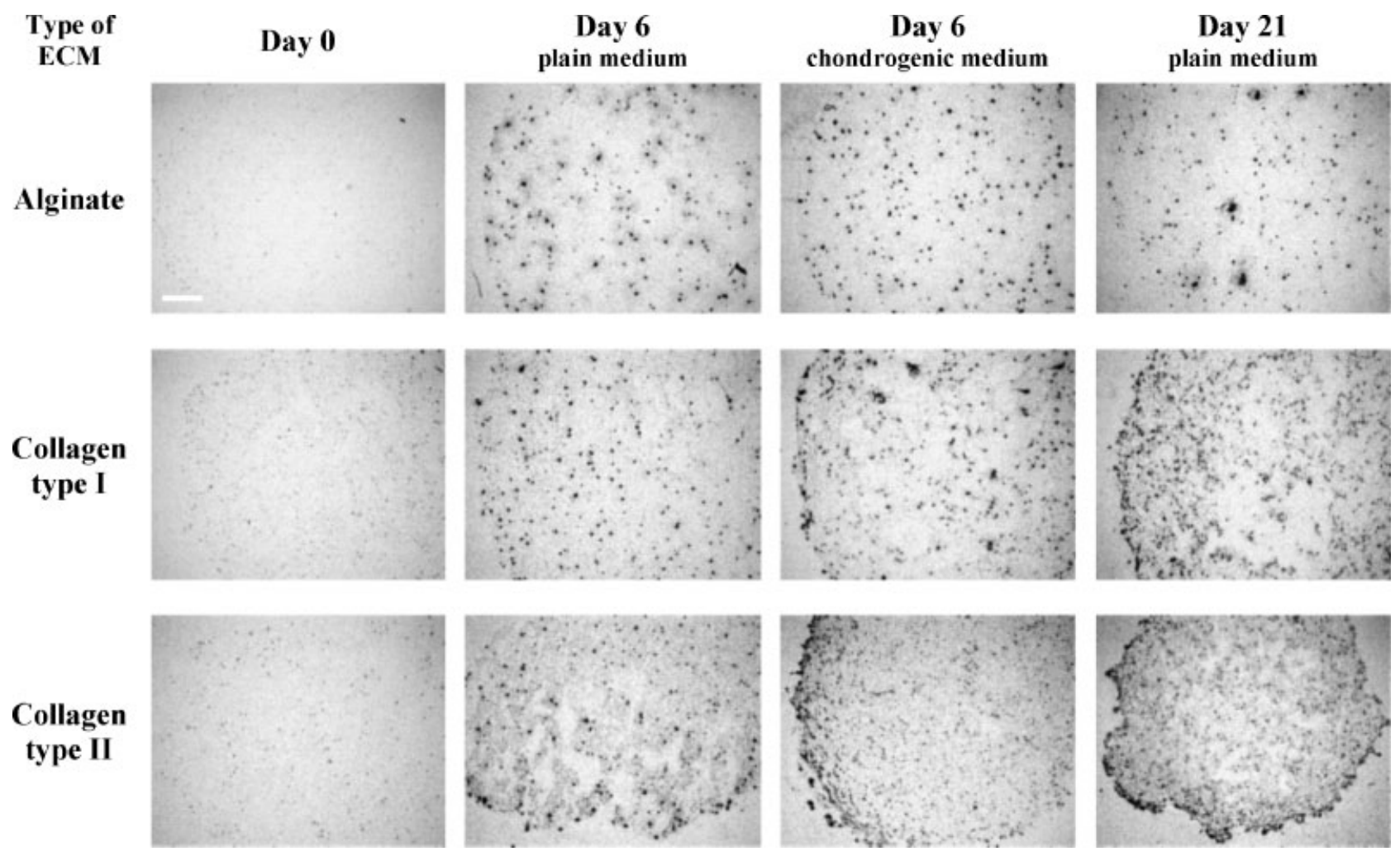

Figure 7. In situ hybridization of the alginate, collagen type I and II hydrogels on day 0,6 , and 21 for detection of agg mRNA. Scale bar $250 \mu \mathrm{m}$. 

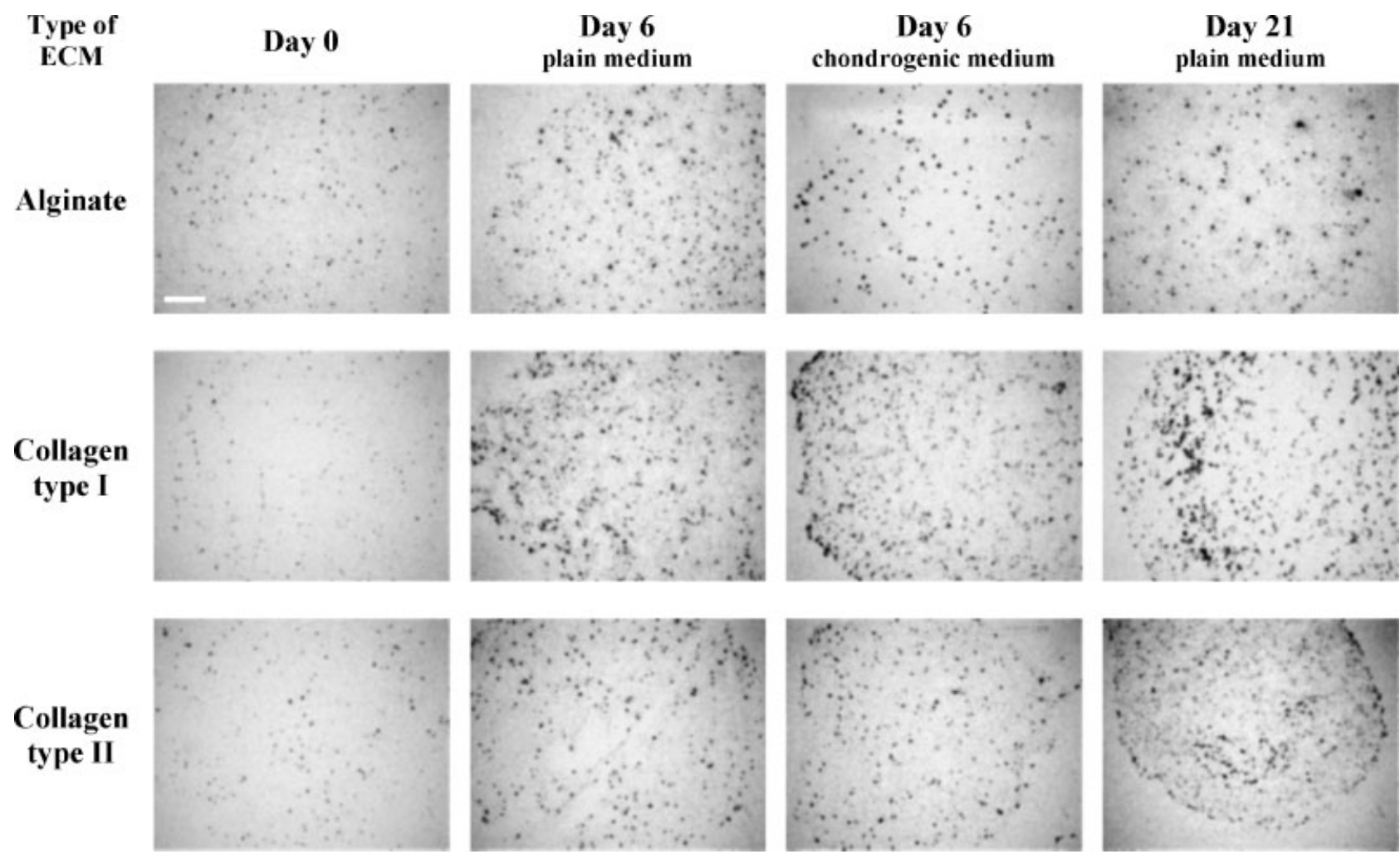

Figure 8. In situ hybridization of the alginate, collagen type I and II hydrogels on day 0,6 , and 21 for detection of coll $1 \mathrm{mRNA}$. Scale bar $250 \mu \mathrm{m}$.

was the highest, confirming the previous suggestion that collagen was the dominant factor for MSC chondrogenesis.

\section{DISCUSSION}

By analyzing gene and protein expression, we have demonstrated the influence of various 3-D hydrogel cultures in inducing and maintaining MSC chondrogenic differentiation. Chondrogenesis of bovine MSCs occurred under serumfree condition and was greatly enhanced in media containing TGF $\beta 1$. Among the different types of hydrogels, collagens type I and II showed the greatest degree of induced differentiation. Between the two types of collagen, type II was slightly better based on cell morphology and chondrogenic gene expression panel.

In order to resolve and understand the complexities of chondrogenesis, it is necessary to follow the process through different culture systems since each of these has certain limitations (Sekiya et al., 2002). Using a bovine experimental model, we have previously analyzed MSC chondrogenesis in monolayer cultures in response to TGF $\beta 1$ stimulation (Bosnakovski et al., 2005). We also demonstrated that bovine MSC has the potential for self-inducing chondrogenic differentiation independent of any externally added biostimulants, if strong cell-cell interaction in the condensate pellet culture system is allowed (Bosnakovski et al., 2004). Having already determined the importance of strong cellcell interaction and the influence of TGF $\beta 1$ in MSC chondrogenesis, we proceeded to assess the influence of $\mathrm{ECM}$ on MSC chondrogenic differentiation.
It is well known that cells must interact with their microenvironment, from where soluble and insoluble signals trigger physiological responses through contact with the cell surface to maintain homeostasis. Various materials incorporated in 3-D culture systems have been shown to be useful tools in studying chondrogenesis, chondrocytes, and matrix biology (Qi and Scully, 2002; Wayne et al., 2005). In order to clarify the influence of the collagen ECM on MSC differentiation, we used two control groups. One was a monolayer culture and the other was a well-documented alginate hydrogel that allows certain macromolecules, such as collagen fibers, to be incorporated within it. Alginate is a polysaccharide extracted from seaweed that forms an ionic gel in the presence of divalent cations such as Ca. Easy manipulation of cell density in suspensions of this type of culture offers a well-controlled system for studying cell-cell and cell-matrix interactions. Chondrocytes encapsulated in alginate remain differentiated, as opposed to cells cultured in monolayers, which become fibroblastic (Hauselmann et al., 1994). Moreover, MSCs in beads of this polymer that were cultured in medium containing TGF or BMP-2, -6 , or -9 underwent chondrogenic differentiation (Ma et al., 2003; Majumdar et al., 2001). Bovine MSCs seeded in alginate beads also maintained a spherical form and increased the expression of chondrocyte-specific genes under TGF $\beta 1$ treatment.

In the present trial, the cell-matrix interaction was the priority; therefore, the MSCs were cultured at a low initial seeding density $\left(1-2 \times 10^{6}\right.$ cells $/ \mathrm{mL}$ hydrogel solution), and we attempted to reduce the alginate percentage in the 
collagen hydrogels as much as possible. It was reported that the most prominent MSC chondrogenesis in cells cultured in an alginate layer occurs at an initial density of $25 \times 10^{6}$ cell/ $\mathrm{mL}$, while GAG synthesis dropped off precipitously in cultures of lower cell density (Kavalkovich et al., 2002).

Collagen type I is a major organic component of bones. Osteoblasts maintain their phenotype when cultured in collagen type I containing ECM, while MSCs undergo osteogenesis (Lynch et al., 1995; Mizuno et al., 1997). The $\alpha 2$ integrin subunit is a component of a major collagen type I receptor $\alpha 2 \beta 1$ integrin. Interaction of this subunit with collagen type I leads to osteoblastic differentiation of MSCs, which is a crucial event in the expression of the osteogenic phenotype (Mizuno et al., 2000). Chondrocytes cultured in collagen type I gel grew in three dimensions, accumulating a cartilaginous ECM while maintaining their round morphology during the culture period (Kimura et al., 1987; Uchio et al., 2002). Furthermore, a cartilage defect was partially repaired when human autologous culture-expanded MSCs engineered in a collagen type I gel were transplanted into an osteoarthritic knee (Wakitani et al., 2002). Our results showed that cells cultured in collagen type I hydrogel and in medium containing TGF $\beta 1$, and dexamethasone expressed significantly high levels of coll 1 mRNA. MSCs undergo osteogenic differentiation upon treatment with dexamethasone or TGF $\beta 1$, which is followed by increased expression of coll 1 mRNA (Andrades et al., 1999; Gronthos et al., 2003; Phinney et al., 1999). Damaged articular cartilage is usually substituted by fibrous cartilage of which collagen $\mathrm{I}$ is a component. We analyzed the influence of collagen type I on MSCs as we were interested in how collagen type I would affect MSC chondrogenesis prior to cell transplantation in a cartilage defect. It appears that collagen type I ECM in combination with TGF $\beta 1$ and dexamethasone induced both chondrogenesis and osteogenesis, while collagen type II biases towards chondrogenesis. Furthermore, hydrolyzed collagen type II and hydrolyzed collagen type I were able to stimulate collagen type II production in chondrocytes to almost the same extent (Oesser and Seifert, 2003).

Collagen type II is a dominant component of hyaline cartilage. Chondrocytes bind to collagen type II ligands through $\alpha 1 \beta 1, \alpha 2 \beta 1$, and $\alpha 10 \beta 1$ integrins resulting in the formation of signaling complexes that play roles in differentiation, matrix remodeling, response to mechanical stimulation, and cell survival (Loeser, 2002). Mitogenactivated protein (MAP) kinase appears to play a central role in mediating the downstream signal from integrins, which can regulate gene expression through activation of transcription factors such as AP-1 and NFkB. Our results clearly demonstrated that the presence of collagen type II in the ECM has the potential to induce and stimulate chondrogenesis. Among all analyzed hydrogels, collagen type II was the most favorable ECM for expressing the chondrogenic phenotype since it resulted in upregulation of each analyzed chondrogenic gene and synthesis of collagen type II and GAG. Upregulation of sox9, coll 2, agg, COMP, and coll 10 mRNA are believed to represent the physiological adaptation of MSCs to a specialized environment of the articular matrix, which could be partly mediated by collagen type II. Even, results to be most convincing, level of coll 1 mRNA, which is an indicator of chondrocyte de-differentiation, was the lowest with a tendency of decreasing (Fig 5) (Schnabe et al., 2002). Van der Kraan et al. (2002) found that collagen type II is a better matrix for chondrocytes to express their phenotype than collagen type I. Chondrocytes significantly upregulated DNA and proteoglycan synthesis in a concentration-dependent fashion, according to the presence of collagen type II in the ECM (Scully et al., 2001). In our trial, cell proliferation was also stimulated in collagencontaining hydrogels (data not shown). An earlier investigation that used collagen-GAG matrices found that while the majority of cultured canine chondrocytes seeded in type I collagen had a fibroblastic morphology, the majority of the cells in type II collagen matrices had a chondrocyte morphology and displayed an increase in GAG and collagen type II production (Nehrer et al., 1997; Veilleux et al., 2004).

TGF $\beta 1$, which is a well-documented potent chondrogenic factor, is stored in a significant concentration in articular cartilage, indicating that it is integral to chondrocyte and matrix homeostasis (Pedrozo et al., 1998). The results from our previous (Bosnakovski et al., 2005) and present studies clearly indicate that MSCs cultured under various culture conditions and treated with TGF $\beta 1$ undergo chondrogenic differentiation, which is time- and dose-dependent with respect to the stimulants. TGF $\beta 1$ exerts its effect through a high-affinity interaction with a heteromeric receptor complex (type I and II) that comprises two structurally related serinethreonine kinases. It transduces its signals through the Smad pathway, leading to the activation of the $\operatorname{sox} 9$ transcription mechanisms (Attisano and Wrana, 2002; Hatakeyama et al., 2003). Chondrogenesis (by all parameters) was most prominently induced in the cells cultured in collagen type II ECM and treated with TGF $\beta 1$. We demonstrated that collagen type II ECM and TGF $\beta 1$ individually had the potential to induce chondrogenesis and that the best differentiation was achieved when these two factors were combined. The same effect was reported in chondrocytes, and the specific regulation of TGF $\beta 1$ in the presence of collagen type II was hypothesized to occur through the binding of $\beta 1$ integrin and its action at the transcriptional, posttranslational, or both levels (Scully et al., 2001). This also confirms that signals received by cells from a soluble regulator such as TGF $\beta 1$ depend on a combination of factors such as mechanical stimuli, presence of the regulators at the cell differentiation level, and the presence of specific pericellular matrix molecules, for example, collagen type II (Vivien et al., 1990). It was proven by means of stimulating cells cultured in different conditions by exogenous TGF $\beta 1$ that the mechanism of action of TGF $\beta 1$ and collagen on chondrocytes is different; however, at the same time, these factors do interact. Cells treated with TGF $\beta 1$ produce endogenous TGF $\beta 1$; however, expression of the endogenous product was downregulated in a dose-dependent manner by 
the presence of collagen types I or II in the ECM (Qi and Scully, 2002). Shakibaei et al. (1999) reported that the expression of the docking protein Shc, which is associated with the Grb2 adaptor protein and the Ras signal pathway, occurs only when chondrocytes were bound to collagen type II or anti- $\beta 1$ integrin antibodies. This expression increased with the addition of IGF-I, suggesting collaboration between integrins and growth factors in a common/shared biochemical-signaling pathway. Furthermore, the binding of chondrocyte integrins to ECM molecules, such as fibronectin, results in the intracellular formation of focal adhesion plagues, which is a prerequisite for cells to respond to growth factors such as FGF and IGF-I (Clancy et al., 1997; Martin and Buckwalter, 1998).

In conclusion, to the best of our knowledge, the current study is the first to provide evidence that collagen type II, which acts as a physiological articular cartilage matrix, can initiate and maintain MSC chondrogenesis, and that it enhances the effect of TGF $\beta 1$. Further understanding of the cell response to ECM will allow more rational designing and development of hydrogels and scaffolds for studying MSC chondrogenic differentiation, articular cartilage development and degeneration, and would advance cartilage tissue engineering.

We thank Dr. Toshihiko Iwanaga; Department of Cytology and Histology, Graduate School of Medicine, Hokkaido University for assistance in situ hybridization; Dr. Rita Perlingeiro and Dr. Michael Kyba; University of Texas, Southwestern Medical Center at Dallas for the help in preparation of the article.

\section{References}

Andrades JA, Han B, Becerra J, Sorgente N, Hall FL, Nimni ME. 1999. A recombinant human TGF-beta1 fusion protein with collagen-binding domain promotes migration, growth, and differentiation of bone marrow mesenchymal cells. Exp Cell Res 250:485-498.

Attisano L, Wrana JL. 2002. Signal transduction by the TGF-beta superfamily. Science 296:1646-1647.

Batorsky A, Liao J, Lund AW, Plopper GE, Stegemann JP. 2005. Encapsulation of adult human mesenchymal stem cells within collagen-agarose microenvironments. Biotechnol Bioeng 3 92:492500 .

Bosnakovski D, Mizuno M, Kim G, Ishiguro T, Okumura M, Iwanaga T, Kadosawa T, Fujinaga T. 2004. Chondrogenic differentiation of bovine bone marrow mesenchymal stem cells in pellet cultural system. Exp Hematol 32:502-509.

Bosnakovski D, Mizuno M, Kim G, Takagi S, Okumura M, Fujinaga T. 2005. Isolation and multilineage differentiation of bovine bone marrow mesenchymal stem cells. Cell Tissue Res 319:243-253.

Clancy RM, Rediske J, Tang X, Nijher N, Frenkel S, Philips M, Abramson SB. 1997. Outside-in signaling in the chondrocyte. Nitric oxide disrupts fibronectin-induced assembly of a subplasmalemmal actin/rho A/ focal adhesion kinase signaling complex. J Clin Invest 100:17891796.

Comper WP. 1996. Extracellular matrix, molecular components and interactions. Vol 2. Amsterdam: Harwood Academic.

Eerola I, Salminen H, Lammi P, Lammi M, von der Mark K, Vuorio E, Saamanen AM. 1997. Type X collagen, a natural component of mouse articular cartilage: Association with growth, aging, and osteoarthritis. Arthritis Rheum 41:1287-1295.

Elisseeff JH, Lee A, Kleinman HK, Yamada Y. 2002. Biological response of chondrocytes to hydrogels. Ann NY Acad Sci 961:118-122.

Gibson G, Lin DL, Roque M. 1997. Apoptosis of terminally differentiated chondrocytes in culture. Exp Cell Res 233:372-382.

Gronthos S, Zannettino AC, Hay SJ, Shi S, Graves SE, Kortesidis A, Simmons PJ. 2003. Molecular and cellular characterisation of highly purified stromal stem cells derived from human bone marrow. J Cell Sci 116:1827-1835.

Haas AR, Tuan RS. 1999. Chondrogenic differentiation of murine C3H10T1/ 2 multipotential mesenchymal cells: II Stimulation by bone morphogenetic protein-2 requires modulation of $\mathrm{N}$-cadherin expression and function. Differentiation 64:77-89.

Hall BK, Miyake T. 1995. Divide, accumulate, differentiate: Cell condensation in skeletal development revisited. Int J Dev Biol 39: 881-893.

Hatakeyama Y, Nguyen J, Wang X, Nuckolls GH, Shum L. 2003. Smad signaling in mesenchymal and chondroprogenitor cells. J Bone Joint Surg Am 85:13-18.

Hauselmann HJ, Fernandes RJ, Mok SS, Schmid TM, Block JA, Aydelotte MB, Kuettner KE, Thonar EJ. 1994. Phenotypic stability of bovine articular chondrocytes after long-term culture in alginate beads. J Cell Sci 107:17-27.

Heng BC, Cao T, Haider HK, Wang DZ, Sim EK, Ng SC. 2004. An overview and synopsis of techniques for directing stem cell differentiation in vitro. Cell Tissue Res 315:291-303.

Huang CY, Reuben PM, D'Ippolito G, Schiller PC, Cheung HS. 2004. Chondrogenesis of human bone marrow-derived mesenchymal stem cells in agarose culture. Anat Rec 278:428-436.

Indrawattana N, Chen G, Tadokoro M, Shann LH, Ohgushi H, Tateishi T, Tanaka J, Bunyaratvej A. 2004. Growth factor combination for chondrogenic induction from human mesenchymal stem cell. Biochem Biophys Res Commun 30:914-919.

Jiang Y, Vaessen B, Lenvik T, Blackstad M, Reyes M, Verfaillie CM. 2002a. Multipotent progenitor cells can be isolated from postnatal murine bone marrow, muscle, and brain. Exp Hematol 30:896-904.

Jiang Y, Jahagirdar BN, Reinhardt RL, Schwartz RE, Keene CD, OrtizGonzalez XR, Reyes M, Lenvik T, Lund T, Blackstad M, Du J, Aldrich S, Lisberg A, Low WC, Largaespada DA, Verfaillie CM. 2002b. Pluripotency of mesenchymal stem cells derived from adult marrow. Nature 418:41-49.

Kavalkovich KW, Boynton RE, Murphy JM, Barry F. 2002. Chondrogenic differentiation of human mesenchymal stem cells within an alginate layer culture system. In Vitro Cell Dev Biol Anim 38:457-466.

Kimura T, Yasui N, Ohsawa S, Ono K. 1987. Chondrocytes embedded in collagen gels maintain cartilage phenotype during long-term cultures. Clin Orthop 186:231-239.

Krause DS, Theise ND, Collector MI, Henegariu O, Hwang S, Gardner R, Neutzel S, Sharkis SJ. 2001. Multi-organ, multi-lineage engraftment by a single bone marrow-derived stem cell. Cell 105:369-377.

Lemare F, Steimberg N, Le Griel C, Demignot S, Adolphe M. 1998. Dedifferentiated chondrocytes cultured in alginate beads: Restoration of the differentiated phenotype and of the metabolic responses to interleukin-1beta. J Cell Physiol 176:303-313.

Loeser RF. 2002. Integrins and cell signaling in chondrocytes. Biorheology 39:119-124.

Lynch MP, Stein JL, Stein GS, Lian JB. 1995. The influence of type I collagen on the development and maintenance of the osteoblast phenotype in primary and passaged rat calvarial osteoblasts: Modification of expression of genes supporting cell growth, adhesion, and extracellular matrix mineralization. Exp Cell Res 216:35-45.

Ma HL, Hung SC, Lin SY, Chen YL, Lo WH. 2003. Chondrogenesis of human mesenchymal stem cells encapsulated in alginate beads. J Biomed Mater Res 64:273-281.

Mackay AM, Beck SC, Murphy JM, Barry FP, Chichester CO, Pittenger MF. 1998. Chondrogenic differentiation of cultured human mesenchymal stem cells from marrow. Tissue Eng 4:415-428. 
Majumdar MK, Thiede MA, Mosca JD, Moorman M, Gerson SL. 1998. Phenotypic and functional comparison of cultures of marrow-derived mesenchymal stem cells (MSCs) and stromal cells. J Cell Physiol 176: $57-66$.

Majumdar MK, Wang E, Morris EA. 2001. BMP-2 and BMP-9 promotes chondrogenic differentiation of human multipotential mesenchymal cells and overcomes the inhibitory effect of IL-1. J Cell Physiol 189:275-284.

Martin JA, Buckwalter JA. 1998. Effects of fibronectin on articular cartilage chondrocyte proteoglycan synthesis and response to insulin-like growth factor-I. J Orthop Res 16:752-757.

Mizuno M, Shindo M, Kobayashi D, Tsuruga E, Amemiya A, Kuboki Y. 1997. Osteogenesis by bone marrow stromal cells maintained on type I collagen matrix gels in vivo. Bone 20:101-107.

Mizuno M, Fujisawa R, Kuboki Y. 2000. Type I collagen-induced osteoblastic differentiation of bone-marrow cells mediated by collagen-alpha2 beta1 integrin interaction. J Cell Physiol 184:207-213.

Mueller SM, Glowacki J. 2001. Age-related decline in the osteogenic potential of human bone marrow cells cultured in three-dimensional collagen sponges. J Cell Biochem 82:583-590.

Muir H. 1995. The chondrocyte, architect of cartilage. Biomechanics, structure, function and molecular biology of cartilage matrix macromolecules. Bioessays 17:1039-1048.

Muraglia A, Cancedda R, Quarto R. 2000. Clonal mesenchymal progenitors from human bone marrow differentiate in vitro according to a hierarchical model. J Cell Sci 113:1161-1166.

Nehrer S, Breinan HA, Ramappa A, Shortkroff S, Young G, Minas T, Sledge CB, Yannas IV, Spector M. 1997. Canine chondrocytes seeded in type I and type II collagen implants investigated in vitro. J Biomed Mater Res 38:288.

Oesser S, Seifert J. 2003. Stimulation of type II collagen biosynthesis and secretion in bovine chondrocytes cultured with degraded collagen. Cell Tissue Res 311:393-399.

Orlic D, Kajstura J, Chimenti S, Jakoniuk I, Anderson SM, Li B, Pickel J, McKay R, Nadal-Ginard B, Bodine DM, Leri A, Anversa P. 2001. Bone marrow cells regenerate infarcted myocardium. Nature 410:701-705.

Pedrozo HA, Schwartz Z, Gomez R, Ornoy A, Xin-Sheng W, Dallas SL, Bonewald LF, Dean DD, Boyan BD. 1998. Growth plate chondrocytes store latent transforming growth factor (TGF)-beta 1 in their matrix through latent TGF-beta 1 binding protein-1. J Cell Physiol 177:343354.

Phinney DG, Kopen G, Righter W, Webster S, Tremain N, Prockop DJ. 1999. Donor variation in the growth properties and osteogenic potential of human marrow stromal cells. J Cell Biochem 75:424-436.

Pittenger MF, Martin BJ. 2004. Mesenchymal stem cells and their potential as cardiac therapeutics. Circ Res 95:9-20.

Pittenger MF, Mackay AM, Beck SC, Jaiswal RK, Douglas R, Mosca JD, Moorman MA, Simonetti DW, Craig S, Marshak DR. 1999. Multilineage potential of adult human mesenchymal stem cells. Science 284:143-147.

Ponticiello MS, Schinagl RM, Kadiyala S, Barry FP. 2000. Gelatin-based resorbable sponge as a carrier matrix for human mesenchymal stem cells in cartilage regeneration therapy. J Biomed Mater Res 52:246-255.

Poole AR, Kojima T, Yasuda T, Mwale F, Kobayashi M, Laverty S. 2001. Composition and structure of articular cartilage: A template for tissue repair. Clin Orthop 391 Suppl:S26-S33.

Qi WN, Scully SP. 2002. Extracellular collagen regulates expression of transforming growth factor-beta1 gene. J Orthop Res 18:928-932.

Reyes M, Lund T, Lenvik T, Aguiar D, Koodie L, Verfaillie CM. 2001. Purification and ex vivo expansion of postnatal human marrow mesodermal progenitor cells. Blood 98:2615-2625.
Schnabel M, Marlovits S, Eckhoff G, Fichtel I, Gotzen L, Vecsei V, Schlegel J. 2002. De differentiation-associated changes in morphology and gene expression in primary human articular chondrocytes in cell culture. Osteoarthritis Cartilage 10:62-70.

Schulze-Tanzil G, de Souza P, Villegas Castrejon H, John T, Merker HJ, Scheid A, Shakibaei M. 2002. Redifferentiation of dedifferentiated human chondrocytes in high-density cultures. Cell Tissue Res 308:371379.

Scully SP, Lee JW, Ghert PMA, Qi W. 2001. The role of the extracellular matrix in articular chondrocyte regulation. Clin Orthop 391:S72-S89.

Sekiya I, Vuoristo JT, Larson BL, Prockop DJ. 2002. In vitro cartilage formation by human adult stem cells from bone marrow stroma defines the sequence of cellular and molecular events during chondrogenesis. Proc Natl Acad Sci USA 99:4397-4402.

Sekiya I, Larson BL, Vuoristo JT, Cui JG, Prockop DJ. 2004. Adipogenic differentiation of human adult stem cells from bone marrow stroma (MSCs). J Bone Miner Res 19:256-264.

Shakibaei M, John T, De Souza P, Rahmanzadeh R, Merker HJ. 1999. Signal transduction by beta1 integrin receptors in human chondrocytes in vitro: Collaboration with the insulin-like growth factor-I receptor. Biochem J 342 Pt 3:615-623.

Sottile V, Halleux C, Bassilana F, Keller H, Seuwen K. 2002. Stem cell characteristics of human trabecular bone-derived cells. Bone 30:699704.

Tsuchiya H, Kitoh H, Sugiura F, Ishiguro N. 2003. Chondrogenesis enhanced by overexpression of sox 9 gene in mouse bone marrow-derived mesenchymal stem cells. Biochem Biophys Res Commun 301:338343.

Uchio Y, Ochi M, Matsusaki M, Kurioka H, Katsube K. 2002. Human chondrocyte proliferation and matrix synthesis cultured in Atelocollagen gel. J Biomed Mater Res 50:138-143.

Van der Kraan PM, Buma P, van Kuppevelt T, van den Berg WB. 2002. Interaction of chondrocytes, extracellular matrix and growth factors: Relevance for articular cartilage tissue engineering. Osteoarthritis Cartilage 10:631-637.

Veilleux NH, Yannas IV, Spector M. 2004. Effect of passage number and collagen type on the proliferative, biosynthetic, and contractile activity of adult canine articular chondrocytes in type I and II collagenglycosaminoglycan matrices in vitro. Tissue Eng 10:119-127.

Vivien D, Galera P, Lebrun E, Loyau G, Pujol JP. 1990. Differential effects of transforming growth factor-beta and epidermal growth factor on the cell cycle of cultured rabbit articular chondrocytes. J Cell Physiol 143:534545.

Wagers AJ, Weissman IL. 2004. Plasticity of adult stem cells. Cell 116:639_ 648.

Wakitani S, Imoto K, Yamamoto T, Saito M, Murata N, Yoneda M. 2002. Human autologous culture expanded bone marrow mesenchymal cell transplantation for repair of cartilage defects in osteoarthritic knees. Osteoarthritis Cartilage 10:199-206.

Wayne JS, McDowell CL, Shields KJ, Tuan RS. 2005. In vivo response of polylactic acid-alginate scaffolds and bone marrow-derived cells for cartilage tissue engineering. Tissue Eng 11:953-963.

Woodbury D, Schwarz EJ, Prockop DJ, Black IB. 2000. Adult rat and human bone marrow stromal cells differentiate into neurons. J Neurosci Res 61: $364-370$

Zaucke F, Dinser R, Maurer P, Paulsson M. 2001. Cartilage oligomeric matrix protein (COMP) and collagen IX are sensitive markers for the differentiation state of articular primary chondrocytes. Biochem $\mathrm{J} 358$ : $17-24$.

Zuk PA, Zhu M, Ashjian P, De Ugarte DA, Huang JI, Mizuno H, Alfonso ZC, Fraser JK, Benhaim P, Hedrick MH. 2002. Human adipose tissue is a source of multipotent stem cells. Mol Biol Cell 13:4279-4295. 